\title{
Pengetahuan Seputar Entrepreneurial Behaviour
}

Nama: Muhammad.Alvin.Arkananta.Syam

Email: alvinas2751@gmail.com

Entrepreneurial Behaviour merupakan salah satu jenis orientasi perilaku yang mengammbarkan kecenderungan atau watak seseorang untuk berwirausaha. Disaat terjadinya Entrepreneurial Behaviour, kinerja pendanaan dipengaruhi oleh informasi yang diungkapkan tentang orientasi kewirausahaan dari usaha baru (Calic \& Shevchenko, 2020). Open Innovation didefinisikan sebagai model manajemen inovasi di mana organisasi membuka proses inovasi mereka dan menggabungkan dan teknologi yang dikembangkan secara internal dan eksternal untuk menciptakan sebuah nilai (value), (Pedersen, 2020). Risk Governance merupakan metodologi inti untuk penilaian risiko bencana mencakup penilaian bahaya, keterpaparan dan kerentanan. Risk Governance juga banyak digunakan dalam konteks kesehatan, keselamatan, dan lingkungan. Hal ini melibatkan evaluasi kondisi kerentanan yang ada, bahaya yang akan datang, paparan yang ada dan kapasitas pencegahan saat ini (Chatterjee, et al., 2020).

Pada Artikel Pratono (2018,a) dalam mengukur tingkat pengelolaan resiko menggunakan Product Development, Karena Product Development bisa membantu dalam menyediakan 2 mediasi yaitu antara trust (kepercayaan) dan Firm Performance (Kinerja Perusahaan) dan Network Structure (Struktur Jaringan) dan Firm Performance (Kinerja Perusahaan). Dimana di mediasi pertama Perusahaan dengan Struktur jaringan yang superior mungkin lebih mampu memanfaatkan kapabilitas pengembangan produk internalnya dan dengan demikian dapat meningkatkan kinerja mereka sehingga dapat mengatasi tingkat pengelolaan resiko perusahaan tersebut, dan untuk mediasi yang kedua Kepercayaan (Trust) adalah sumber daya yang penting dalam menghadapi resiko kegagalan pengembangan produk. Dimana pengembangan Kepercayaan disini merupakan mekanisme pengembangan produk dimana perusahaan dapat memperoleh keuntungan dan Organisasi yang memiliki kepercayaan tinggi memperbolehkan "orang-orangnya" (karyawan) untuk berinovasi dan berfikir kreatif.

Pratono $(2018, b)$ mengukur tingkat pengelolaan resiko berdasarkan empat variable laten, yaitu risk-taking behaviour, firm performance, pricing capability dan information technological turbulence. Untuk pengukuran setiap konstruk menggunakan Langkah-langkah subyektif, yang menjadi strategi penelitian untuk mengatasi kapasitas yang kurang layak atau keterbukaan informasi keuangan swasta dari UMKM. Untuk variable risk-taking behaviour ada delapan cara untuk mengukurnya, dimana itu mencakup enam pernyataan: "kecenderungan yang kuat untuk proyek berisiko tinggi", "tindakan berani dan meluas", "pembiayaan untuk bisnis baru", "bisnis tanpa sumber daya yang memadai," "pertumbuhan bisnis yang tinggi bahkan selama ketidakpastian" dan " cepat menghabiskan uang untuk solusi potensial. " Ada juga dua pertanyaan terbalik yang menyoroti "postur menunggu dan melihat untuk meminimalkan risiko" sebagai pertanyaan terbalik, dan "mempelajari masalah sebelum menerapkan sumber daya". Untuk Firm Performance melibatkan kinerja pertumbuhan penjualan relatif terhadap pesaing, laba atas aset, laba atas investasi, dan laba atas penjualan selama tiga tahun terakhir. Technological Turbulence diukurnya terdiri dari lima hal yaitu "perubahan pesat", "terobosan teknologi", "membuat ide baru" dan "menyediakan peluang besar". Dan yang terakhir ada Pricing Capability dimana untuk mengukur variabel ini, terdiri dari 5 cara atau penyebutan, yaitu "keterampilan penetapan harga", "keefektifan penetapan harga", "memonitor penetapan harga saingan/kompetitor", dan yang terakhir "respon terhadap taktik penetapan harga kompetitor" (Pratono, A.H. ,2018 B). 
Reference

Calic, G., \& Shevchenko, A. (2020, Mei 13). How signal intensity of behavioral orientations affects crowdfunding performance: The role of entrepreneurial orientation in crowdfunding business ventures. Journal of Business Research, 115, 204-220.

Chatterjee, R., Bajwa, S., Dwivedi, D., Kanji, R., Ahammed, M., \& Shaw, R. (2020, Juni 02). COVID-19 Risk Assessment Tool: Dual application of risk communication and risk governance. Contents lists available at ScienceDirect Progress in Disaster Science, 7, 100-109.

Pedersen, K. (2020, Februari 18). What can open innovation be used for and how does it create value? Government Information Quarterly, 37, 101-459.

Pratono, A.H. (2018a) Network structure and open innovation: the role of trust in product development. International Journal of Business Innovation and Research, 15(1), 44-61

Pratono, A.H.(2018b). Does firm performance increase with risk-taking behavior under information technological turbulence?: Empirical evidence from Indonesian SMEs, The Journal of Risk Finance, 19(4). 361-378. 